\title{
HUBUNGAN ANTARA KOMITMEN AFEKTIF DENGAN KOMPETENSI ORIENTASI LAYANAN PELANGGAN (CUSTOMER SERVICE ORIENTATION) PADA PRAMUNIAGA
}

\author{
Endah Mujiasih \\ Fakultas Psikologi, Universitas Diponegoro \\ J1. Prof. Soedharto SH Tembalang Semarang 50275 \\ ema_ariesta@yahoo.com
}

\begin{abstract}
Affective commitment or emotional self-involvement in the organization was the willingness of employees to do their best for the organization benefit. The purpose of this study was to determine the relationship between affective commitment with customer service orientation. The population in this study were employees of Company " $\mathrm{X}$ " in Semarang. The sampling technique used is simple random sampling. Data analysis using simple regression indicate that there was a positive and significant relationship between affective commitment with customer service orientation coefficient $(\mathrm{r}=0.516 ; \mathrm{p}<.001)$. These results prove that the hypothesis was accepted. The higher the affective commitment will be followed with the higher salesperson's customer service orientation. Conversely, the lower the affective commitment will be followed with the lower the salesperson's customer service orientation.
\end{abstract}

Keywords: affective commitment; competency; customer service orientation

\begin{abstract}
Abstrak
Komitmen afektif atau keterlibatan diri secara emosional dalam organisasi, yaitu kesediaan karyawan untuk berusaha sebaik mungkin demi kepentingan organisasi. Tujuan penelitian ini untuk mengetahui hubungan antara komitmen afektif dengan kompetensi orientasi layanan Customer Service Orientation). Populasi dalam penelitian ini adalah karyawan Perusahaan " $\mathrm{X}$ " di Semarang. Teknik sampling yang digunakan adalah simple random sampling. Analisis data penelitian menggunakan analisis regresi sederhana. Hasil analisis regresi sederhana menunjukkan bahwa terdapat hubungan positif dan signifikan antara komitmen afektif dengan orientasi pelayanan pelanggan (Customer Service Orientation). Koefisien korelasi $\left(\mathrm{r}_{\mathrm{xy}}\right)=0,516$ dengan $\mathrm{p}<0,001$. Hasil tersebut menunjukkan bahwa hipotesis yang mengatakan ada hubungan positif antara komitmen afektif dengan orientasi pelayanan pelanggan (Customer Service Orientation) pada pramuniaga PT. "X" di Semarang diterima. Semakin tinggi komitmen afektif maka semakin tinggi orientasi pramuniaga pada pelayanan pelanggan (CSO tinggi). Sebaliknya, semakin rendah komitmen afektif maka semakin rendah orientasi pramuniaga pada pelayanan pelanggan (CSO rendah).
\end{abstract}

Kata kunci: komitmen afektif; kompetensi; orientasi layanan pelanggan

\section{PENDAHULUAN}

Sebagai falsafah bisnis, konsep pemasaran disusun dengan memasukkan tiga unsur pokok yaitu orientasi pada konsumen, penyusunan kegiatan pemasaran secara integral, dan kepuasan konsumen. Kepuasan konsumen merupakan faktor yang akan menentukan banyak sedikitnya laba yang akan diperoleh perusahaan dalam jangka panjang. Oleh karena itu perusahaan harus dapat memenuhi kebutuhan dan keinginan konsumennya agar tercipta kepuasan konsumen. Namun demikian banyak perusahaan yang kurang memperhatikan kebutuhan (need) dan keinginan (want) pelanggan sehingga mengalami decline. Salah satu kebutuhan pelanggan yang harus diperhatikan adalah layanan pada pelanggan sesuai dengan nilai-nilai pelanggan. Perusahaan yang kurang berorientasi pada pelanggan akan ditinggalkan oleh pelanggannya karena pelanggan berpaling pada kompetitor perusahaan tersebut.

Fokus pada pelanggan dipandang sebagai salah satu faktor yang meningkatkan kinerja suatu organisasi, individu atau tim (Finka, 2014). Namun fokus pada pelanggan menjadi tidak mungkin dapat dilakukan 
perusahaan tanpa didahului oleh fokus pada karyawan. Karyawan merupakan pelanggan internal suatu perusahaan yang juga perlu diperhatikan. Tercapainya pelayanan yang berkualitas pada pelanggan apabila perusahaan juga berorientasi pada pelayanan pada karyawannya. Oleh sebab itu kunci untuk membentuk fokus pada pelanggan adalah ketepatan dalam menempatkan karyawan untuk berhubungan dengan pelanggan dan memberdayakan mereka dalam mengambil tindakan yang diperlukan untuk memuaskan para pelanggan. Jadi unsur yang paling penting dalam pembentukan fokus pada pelanggan adalah interaksi antara karyawan dan pelanggan. Interaksi dengan pelanggan merupakan salah satu upaya saluran hubungan antara pelanggan dan organisasi atau perusahaan (AlHarbi, Heavin, Carton, 2016).

Mutu pelayanan yang diberikan kepada pelanggan eksternal seringkali ditentukan oleh mutu pelayanan karyawan. Perusahaan diharapkan mampu mendorong partisipasi karyawan dalam melakukan perbaikan pelayanan sehingga mutu pelayanan pada pelanggan dapat terjaga. Kepuasan pelanggan dibangun atas dasar beberapa prinsip yang digunakan oleh perusahaan dalam memberikan pelayanan secara tangibles (bukti nyata), realibility (terpercaya, tahan uji), responsiveness (respon, cepat tanggap), assurance (kepastian), empathy (empati). Tjiptono (2007) mengatakan bahwa kualitas layanan pada dasarnya adalah upaya pemenuhan kebutuhan dan keinginan pelanggan serta ketetapan penyampaiannya untuk mengimbangi harapan pelanggan. Meningkatan kompetensi pelayanan dapat dilakukan dengan mengedukasi para karyawan agar karyawan selalu berorientasi dan memiliki kemampuan lebih dalam melayani pelanggannya atau sering juga disebut Customer Service Orientation (CSO).

Becker, Huselid, Ulrich (2001) mengemukakan bahwa kompetensi ditunjukkan dengan karakteristik individu yang terdiri dari pengetahuan (knowledge), keterampilan (skill) dan sikap (attitude). Kompetensi merupakan aspek-aspek pribadi dari seorang pekerja yang memungkinkan untuk mencapai kinerja yang superior. Aspek-aspek pribadi tersebut termasuk sifat, motif, sistem nilai, sikap, pemhetahuan dan keterampilan. Selanjutnya kompetensi akan menggerakkan tingkah laku sedangkan tingkahlaku akan menghasilkan kinerja.

Spencer \& Spencer (1993) mengemukakan bahwa kompetensi adalah karakteristik dari seseorang atau individu yang berkaitan dengan efektivitas kinerja dan atau kinerja superior dalam suatu pekerjaan dan keadaan tertentu. Kompetensi sebagai karakteristik dasar merupakan bagian dari kepribadian individu yang relatif dalam dan stabil, dapat dilihat dan diukur dari perilaku individu yang bersangkutan di tempat kerja atau di berbagai situasi. Sehingga dapat dikatakan bahwa kompetensi seseorang merupakan indikasi dari kemampuan berperilaku seseorang dalam berbagai situasi yang cukup konsisten untuk suatu periode waktu yang cukup panjang dan bukan hal yang kebetulan semata.

Salah satu hal yang dibutuhkan dalam mencapai kepuasan pelanggan adalah kompetensi orientasi pelanggan (customer orientation). Menurut Spencer \& Spencer (1993) Customer Service Orientation (CSO) diartikan sebagai keinginan untuk membantu atau melayani pelanggan baik itu dengan mencari informasi kebutuhan pelanggan, mengambil tanggung jawab untuk menyelesaikan masalah pelanggan bahkan bertindak sebagai seorang penasehat dalam menghadapi masalah dan kebutuhan pelanggan. Hal itu menunjukkan bahwa individu yang memiliki kompetensi CSO merupakan individu yang memiliki kemampuan dalam orientasi membantu dan melayani pelanggan, fokus pada kebutuhan konsumen, memposisikan pelanggan sebagai mitra, fokus sebagai pengguna akhir, dan memperhatikan kepuasan pelanggan Pelanggan adalah pelanggan aktual atau pelanggan akhir dari organisasi yang sama. 
Lebih lanjut Siswanto (2006) menyebutkan bahwa Customer service orientation (CSO) adalah derajat kepedulian seseorang terhadap pekerjaannya sehingga ia terdorong berusaha untuk bekerja dengan lebih baik atau di atas standar. Kesimpulannya kompetensi Orientasi Layanan Pelanggan (Customer Service Orientation) adalah kemampuan yang terkait dengan keinginan membantu atau melayani orang lain untuk memenuhi kebutuhan mereka. Artinya berusaha untuk mengetahui dan memenuhi kebutuhan pelanggan.

Zwell (2000) mengungkapkan bahwa terdapat beberapa faktor yang dapat mempengaruhi kecakapan kompetensi seseorang, yaitu keyakinan dan nilai-nilai, keterampilan, pengalaman, karakteristik kepribadian, motivasi, emosional, kemampuan intelektual,dan budaya organisasi. Keyakinan diri yang dimiliki individu akan mempengaruhi perilaku individu. Demikian pula dengan memperbaiki ketrampilan, individu akan meningkat kecakapannya. Sementara pengalaman menunjang munculnya keahlian dari banyak kompetensi. Faktor lainnya adalah karakteristik kepribadian, serta motivasi yang didapatkan dari pihak lain. Tidak adanya hambatan emosional akan memudahkan penguasaan kompetensi, ditunjang pula dengan kemampuan intelektual untuk memahami konsep dan menganalisa. Faktor lain yang juga penting namun berasal dari luar diri adalah adanya budaya organisasi yang menunjang kompetensi.

Orientasi Layanan Pelanggan (Customer Service Orientation) merupakan kompetensi yang penting dimiliki individu. Kompetensi adalah suatu kemampuan untuk melaksanakan atau melakukan suatu pekerjaan atau tugas yang dilandasi atas ketrampilan dan pengetahuan serta didukung oleh sikap kerja yang dituntut oleh pekerjaan tersebut. Dimensi kompetensi orientasi layanan pelanggan (Customer Service Orientation) menurut Spencer \& Spencer (1993) terdiri dari berfokus pada kebutuhan konsumen, dan inisiatif melakukan usaha untuk melayani pelanggan. Selanjutnya dimensi tersebut yang digunakan dalam penelitian ini. Spencer \& Spencer (1993) menjelaskan lebih lanjut bahwa indikator Kompetensi Orientasi Layanan Pelanggan (Customer Service Orientation) adalah fokus terhadap kemampuan diri sendiri, memberikan pelayanan yang minimal, merespon pelanggan dengan tepat, memelihara komunikasi yang baik, mengambil tanggung jawab pribadi, bertindak untuk pelanggan, menanggapi kebutuhan mendasar pelanggan, dan menggunakan persfektif jangka panjang.

Untuk dapat menciptakan karyawan yang memiliki kemampuan berorientasi pada pelanggan diperlukan karyawan yang mencintai pekerjaannya sehingga akan melakukan pekerjaannya sepenuh hati, hal itu mungkin dimunculkan pada saat karyawan memiliki keterikatan dengan perusahaannya. Harapan perusahaan para karyawan dapat mengidentifikasi visi misi perusahaan dan berkomitmen untuk terlibat secara aktif dalam kegiatan perusahaan. Greenberg dan Baron (2003) mengatakan komitmen individu adalah dimana individu mampu mengidentifikasi dan melibatkan diri di dalam perusahaan secara aktif.

Karyawan yang memiliki kelekatan emosional terhadap perusahaan dikatakan bahwa karyawan tersebut memiliki komitmen afektif. Menurut Shore \& Wayne (dalam Wulandari, 2008) komitmen afektif berhubungan dengan organizational citizens, yaitu karyawan akan melibatkan diri dalam perilaku positif walaupun hal itu bukanlah bagian dari deskripsi kerjanya dikarenakan karyawan memiliki kelekatan emosional dengan organisasinya. Komitmen afektif merupakan jenis komitmen yang paling efektif bagi kinerja perusahaan. Seseorang dengan komitmen afektif tinggi akan memiliki performa kerja yang lebih baik (Meyer, dkk, dalam Wulandari, 2008).

Schultz \& Schultz (2002) menjelaskan bahwa komitmen afektif yaitu keadaan saat individu mempertimbangkan sejauhmana nilai dan 
tujuannya sesuai dengan nilai dan tujuan organisasi. Komitmen afektif menunjukkan suatu kelekatan psikologis terhadap organisasi. Komitmen ini menunjukkan adanya keterlibatan secara mental dan emosional individu terhadap organisasinya (Yuliane, 2003).

Komitmen afektif merupakan bagian dari Komitmen organisasional yang mengacu kepada sisi emosional yang melekat pada diri seorang karyawan terkait keterlibatannya dalam sebuah organisasi. Karyawan yang memiliki komitmen afektif yang kuat akan senantiasa setia terhadap organisasi tempat bekerja oleh karena keinginan untuk bertahan tersebut berasal dari dalam hatinya. Komitmen afektif dapat muncul karena adanya kebutuhan, dan juga adanya ketergantungan terhadap aktivitas-aktivitas yang telah dilakukan oleh organisasi di masa lalu yang tidak dapat ditinggalkan karena akan merugikan. Komitmen afektif ini terbentuk sebagai hasil dari organisasi yang dapat membuat karyawan memiliki keyakinan yang kuat untuk mengikuti segala nilai-nilai organisasi, dan berusaha untuk mewujudkan tujuan organisasi sebagai prioritas pertama, dan karyawan akan juga mempertahankan keanggotaannya (Kartika, 2011). Komitmen ini muncul dan berkembang oleh dorongan adanya kenyemanan, keamanan dan manfaat lain yang dirasakan dalam suatu orgnisasi tempat anggota bekerja (Dessler, 2005). Komitmen afektif merupakan kepentingan tertentu dalam organisasi dimana karyawan secara sukarela dan berpartisipasi aktif dalam kinerja di dalam perusahaan tempatnya bekerja.

Rhoades, Eisenberger, \& Armeli (2001) \& Meyer, Stanley, Hercovitch, \& Topolnytsky (2002) menjelaskan tiga aspek yang terkait dalam komitmen afektif organisasi yaitu keterikatan emosional, kepercayaan dan penerimaan tujuan dan nilai-nilai organisasi, kemauan mengerjakan tugas demi organisasi. Sementara Luthans (2005) mengatakan bahwa komitmen afektif memiliki aspekaspek sebagai berikut, yaitu kelekatan emosional, identifikasi, dan keterlibatan diri dalam organisasi. Kesimpulan yang dapat diambil adalah aspek dalam komitmen afektif karyawan apabila karyawan memiliki keterikatan emosional terhadap perusahaan, mengidentifikasi tujuan dan nilai-nilai perusahaan ke dalam perilaku kerjanya atas dasar kepercayaan pada perusahaan dan kemauan untuk berkinerja melebihi standar minimal yang ditentukan perusahaan.

Reichheld (dalam Nurandini, 2014) menunjukkan bahwa ada korelasi positif antara komitmen karyawan dengan tingkat kinerja perusahaan. Komitmen afektif merupakan bentuk komitmen yang paling diinginkan oleh perusahaan. Karyawan yang memiliki komitmen afektif akan cenderung tetap tinggal (bekerja dalam perusahaan), akan merekomendasikan kepada orang lain bahwa perusahaan tempat bekerjanya merupakan tempat yang bagus untuk bekerja, akan melakukan kerja tambahan untuk perusahaan, serta akan mau memberikan saran-saran bagi perbaikan dan kemajuan perusahaan (Mas'ud, dalam Nurandini, 2014). Sabir, Sohail \& Khan (2011) menyebutkan bahwa komitmen afekif menunjukkan tingkat keterikatan karyawan dengan organisasi termasuk keyakinan, kemauan dan keinginan tentang tujuan organisasi. Komitmen afektif yang baik ditandai dengan adanya semangat kerja yang baik pula dengan diwujudkan dalam perilaku kerja untuk mencapai performa kerja di atas standar.

Berdasarkan latar belakang masalah maka dapat dirumuskan permasalahan dalam penelitian ini, yaitu apakah ada hubungan antara komitmen afektif dengan kompetensi orientasi layanan pelanggan (Customer Service Orientation) pada karyawan PT. " $\mathrm{X}$ " di Semarang. Hipotesis penelitian ini adalah, ada hubungan positif antara komitmen afektif dengan kompetensi orientasi layanan pelanggan (Customer Service Orientation CSO). Semakin tinggi komitmen afektif, maka semakin tinggi kompetensi orientasi layanan pelanggan (Customer Service Orientation - CSO). Sebaliknya, semakin 
rendah komitmen afektif, maka semakin rendah kompetensi orientasi layanan pelanggan (Customer Service Orientation CSO).

\section{METODE}

Variabel yang digunakan dalam penelitian ini adalah Kompetensi Orientasi Layanan Pelanggan (Customer Service Orientation - CSO) sebagai variabel bebas dan Komitmen Afektif sebagai variabel tergantung. Kompetensi Orientasi Layanan Pelanggan (Customer Service Orientation CSO) adalah kemampuan karyawan dalam memfokuskan dan berinisiatif untuk membantu melayani dan menyelesaikan masalah pelanggan. Komitmen afektif adalah keterikatan karyawan secara emosional terhadap perusahaan dimana dia bekerja dan kesediaannya untuk tetap bertahan sebagai anggota dalam perusahaan tersebut serta kerelaan dalam melakukan identifikasi terhadap visi misi, nilai-nilai dan tujuan perusahaan ke dalam perilaku kerjanya.

Metode pengumpulan data yang digunakan dalam penelitian ini dengan Skala Orientasi Layanan Pelanggan dan Skala Komitmen Afektif. Skala Orientasi Layanan Pelanggan dengan model likert disusun dengan mengunakan dimensi berfokus pada kebutuhan konsumen, inisiatif melakukan usaha untuk melayani pelanggan. Skala Orientasi Pada Layanan Pelanggan (Customer Service Orientation) terdiri dari 8 aitem $(\alpha=0,750)$. Skala Komitmen Afektif terdiri dari 22 aitem $(\alpha=0,902$.), mengacu pada aspek komitmen afektif yaitu keterikatan emosional individu dengan organisasi, identifikasi kepercayaan, penerimaan tujuan dan nilai-nilai organisasi, kemauan untuk mengerjakan usaha atas nama organisasi.

Populasi dalam penelitian adalah karyawan PT."X" di Semarang. Adapun karakteristiknya yaitu staf tetap yang memiliki masa kerja minimal 1 tahun, minimal berpendidikan SMA, sehari-hari bertugas sebagai pramuniaga dan menghadapi pelanggan langsung (face to face). Pengambilan sampel dalam penelitian ini dilakukan dengan menggunakan teknik sampling populasi atau teknik sampling jenuh, yaitu dengan cara mengumpulkan semua kemungkinan yang ada sesuai kriteria sampling yang telah ditentukan peneliti (Neuman \& Lawrence, 2007). Jumlah sampel penelitian sebanyak 72 subjek.

Analisis data yang digunakan adalah analisis regresi sederhana. Seluruh perhitungan dalam penelitian ini dilakukan dengan bantuan SPSS 17.0

\section{HASIL DAN PEMBAHASAN}

Sebelum melakukan uji hipotesis, peneliti melakukan uji asumsi yaitu uji normalitas dan uji linieritas, dari uji normalitas menggunakan teknik Kolmogorov-Smirnov Goodness of Fit Test diketahui bahwa data dari kedua variabel berbentuk normal. Untuk variabel komitmen afektif $\mathrm{K}-\mathrm{Z}=0,841$ $(\mathrm{p}=0,479 ; \mathrm{p}>0,05)$, dan untuk variabel orientasi layanan pelanggan $\mathrm{K}-\mathrm{Z}=0,829$ $(\mathrm{p}=0,498 ; \mathrm{p}>0,05)$. Hasil uji linieritas sebagai diketahui linier dengan $\mathrm{F}=50,216$ $(\mathrm{p}<0,001)$.

Hasil uji hipotesis menggunakan analisis regresi sederhana menunjukkan bahwa terdapat hubungan positif dan signifikan antara komitmen afektif dengan orientasi pelayanan pelanggan (Customer Service Orientation). Koefisien korelasi $r_{x y}=0,516$ dengan $\mathrm{p}<0,001$. Hasil tersebut menunjukkan bahwa hipotesis yang mengatakan ada hubungan positif antara komitmen afektif dengan orientasi pelayanan pelanggan (Customer Service Orientation) pada pramuniaga PT. " $X$ " di Semarang diterima. Koefisien determinasi komitmen afektif dan orientasi pelayanan pelanggan (Customer Service Orientation - CSO) pada pramuniaga PT. "X" diperoleh angka $\mathrm{R}^{2}$ sebesar 0,266 . Artinya, komitmen afektif memiliki sumbangan efektif sebesar 0,266 terhadap orientasi pelayanan pelanggan (Customer Service Orientation). Jadi 26,6\% orientasi pelayanan pelanggan (Customer Service 
Orientation) di pengaruhi oleh komitmen afektif, sedangkan sisanya sebesar 73,4 \% dipengaruhi oleh faktor lain yang tidak disertakan dalam penelitian ini.

Peneliti selanjutnya melakukan analisis deskriptif yang bertujuan untuk memberikan deskripsi mengenai subjek penelitian berdasarkan data dari variabel yang diperoleh. Penjelasan selengkapnya disajikan dalam Tabel 1.

Tabel 1. Statistik Deskriptif

\begin{tabular}{clcc}
\hline Variabel & \multicolumn{1}{c}{ Statistik } & Hipotetik & Empirik \\
\hline & $\begin{array}{l}\text { Skor } \\
\text { minimal }\end{array}$ & 22 & 60 \\
Komitmen & Skor & 110 & 92 \\
Afektif & maksimal & & \\
& Mean & 66 & 74,07 \\
& SD & 14,6 & 7,368 \\
& Skor & 8 & 26 \\
Orientasi & minimal & & 38 \\
$\begin{array}{c}\text { Pelayanan } \\
\text { Pelanggan } \\
\text { (Customer }\end{array}$ & Skor & 40 & \\
Mervice & Meansimal & & 31,08 \\
Orientation) & & 24 & 3,183 \\
& & 5,3 & \\
& & &
\end{tabular}

Analisis deskriptif tersebut digunakan untuk menentukan kategorisasi subjek penelitian dalam tiap variabel. Rentang nilai dan kategori skor subjek penelitian variabel komitmen afektif tersaji dalam tabel 2.

Tabel 2

Rentang Nilai dan Kategori Komitmen Afektif

\begin{tabular}{ccc}
\hline Rumus Interval & Rentang Nilai & $\begin{array}{c}\text { Kategori } \\
\text { Skor }\end{array}$ \\
\hline $\mathrm{X} \leq \mathrm{M}-1,5 \mathrm{SD}$ & $\mathrm{X}<44,1$ & $\begin{array}{c}\text { Sangat } \\
\text { Rendah }\end{array}$ \\
$\mathrm{M}-1,5 \mathrm{SD}<\mathrm{X} \leq \mathrm{M}-0 \mathrm{SD}$ & $44.1<\mathrm{X} \leq 66$ & $\begin{array}{c}\text { Rendah } \\
\text { Tinggi }\end{array}$ \\
$\mathrm{M}-0 \mathrm{SD}<\mathrm{X} \leq \mathrm{M}+1.5 \mathrm{SD}$ & $66<\mathrm{X} \leq 87.9$ & $\begin{array}{c}\text { Sangat } \\
\text { tinggi }\end{array}$ \\
$\mathrm{M}+1.5 \mathrm{SD}<\mathrm{X}$ & $87.9<\mathrm{X}$ & \\
\end{tabular}

Tabel 3

Prosentase Kategorisasi Komitmen Afektif

\begin{tabular}{ccc}
\hline $\begin{array}{c}\text { Kategorisasi } \\
\text { Variabel Komitmen }\end{array}$ & Jumlah & Persentase \\
Afektif & & \\
\hline Sangat rendah & 0 & $0 \%$ \\
Rendah & 16 & $22,2 \%$ \\
Tinggi & 56 & $77,8 \%$ \\
Sangat tinggi & 0 & $0 \%$ \\
\hline
\end{tabular}

Rentang nilai dan kategori skor subjek penelitian variabel orientasi pelayanan pelanggan (Customer Service Orientation) pada tabel 4.

Tabel 4

Rentang Nilai dan Kategori CSO

\begin{tabular}{ccc}
\hline Rumus Interval & Rentang Nilai & Kategori Skor \\
$\mathrm{X} \leq \mathrm{M}-1.5$ & $\mathrm{X} \leq 16.05$ & Sangat rendah \\
\hline $\mathrm{M}-1.5 \mathrm{SD}<\mathrm{X} \leq \mathrm{M}-0 \mathrm{SD}$ & $16.05<\mathrm{X} \leq 24$ & Rendah \\
$\mathrm{M}-0 \mathrm{SD}<\mathrm{X} \leq \mathrm{M}+1.5$ & $24<\mathrm{X} \leq 31.95$ & Tinggi \\
$\mathrm{SD}$ & $31.95<\mathrm{X}$ & Sangat tinggi \\
$\mathrm{M}+1.5 \mathrm{SD}<\mathrm{X}$ &
\end{tabular}

Tabel 5

Prosentase Kategorisasi Customer Service Orientation

\begin{tabular}{ccc}
$\begin{array}{c}\text { Kategorisasi } \\
\text { Variabel Orientasi Pelayanan Pelanggan } \\
\text { (Customer Service Orientation) }\end{array}$ & Jumlah & Persentase \\
\hline Sangat rendah & 0 & \\
Rendah & 0 & $0 \%$ \\
Tinggi & 60 & $83.3 \%$ \\
Sangat tinggi & 12 & $16.4 \%$ \\
\hline
\end{tabular}

Berdasarkan uji hipotesis yang sudah dilakukan, menunjukkan bahwa variabel komitmen afekfif memiliki hubungan positif dan signifikan dengan variabel orientasi pelayanan pelanggan (Customer Service Orientation). Artinya, semakin tinggi komitmen afektif maka semakin tinggi orientasi pramuniaga pada pelayanan pelanggan (CSO tinggi). Sebaliknya, semakin rendah komitmen afektif maka semakin rendah orientasi pramuniaga pada pelayanan pelanggan (CSO rendah).

Tingginya komitmen afektif dikarenakan pramuniaga memiliki kebutuhan untuk bekerja untuk mendapatkan penghasilan, penghargaan dalam masyarakat dan kebutuhan untuk beraktualisasi diri. Kebutuhan tersebut dijelaskan pada teori kebutuhan Maslow tentang tingkatan kebutuhan manusia. Tingginya orientasi pelayanan pelanggan (Customer Service Orientation) di karenakan pramuniaga memiliki semangat dalam bekerja dan memiliki inisiatif untuk melakukan usaha secara maksimal dalam melayani pelanggan sebagai bentuk aktualisasi sebagai pramuniaga.

Komitmen afektif merupakan salah satu komponen dari komitmen organisasi. Komitmen organisasi didefinisikan sebagai suatu keadaan dimana seorang karyawan 
memihak pada suatu organisasi tertentu serta tujuan-tujuannya, berniat memelihara keanggotaan dalam organisasi tersebut. Komitmen organisasional adalah suatu nilai personal, dimana seringkali komitmen organisasional mengacu kepada loyalitas terhadap perusahaan atau komitmen terhadap perusahaan (Meyer, Allen \& Smith, 1993). Komitmen afektif ditunjukkan oleh para karyawan dimana mereka menganggap pekerjaan yang dilakukan bukan hanya sebagai rutinitas semata melainkan melakukan pekerjaan dengan senang hati dan tidak terpaksa karena karyawan ada rasa saling memiliki yang kuat terhadap organisasi. Selain itu karyawan juga menunjukkan keterikatan secara emosional dengan organisasi, karyawan berfikir bahwa organisasi membutuhkannya dan karyawanpun membutuhkan organisasi.

Memberikan pelayanan yang tepat sesuai dengan prosedur tentunya di sebuah organisasi telah menetapkan Standard Operational Procedure (SOP) masingmasing, dan sebagai karyawan menjalankan SOP tersebut merupakan sebuah kewajiban yang harus dijalankan dengan baik. Pelayanan atau service dari seorang karyawan bertujuan untuk memenuhi kebutuhan pelanggan dan apa yang diinginkan oleh pelanggan. Kinerja yang diberikan oleh karyawan dapat dinilai atau dilihat dari kualitas layanan yang disampaikan dan karyawan harus memiliki komitmen untuk membantu menyelesaikan masalah konsumen. Karyawan harus bisa peduli terhadap pelanggan, apabila pelanggan menemui masalah, misalnya kebingungan untuk memilih barang-barang yang dibutuhkan, karyawan bisa membantu memecahan masalah tersebut dengan memberikan beberapa saran.

Karyawan dengan komitmen afektif yang kuat, akan bekerja keras dan memberikan kemampuan terbaiknya juga akan bertahan lebih lama dibandingkan dengan karyawan yang memilik komitmen afektif rendah (Meyer, Allen, \& Smith, 1993). Para karyawan yang digunakan sebagai subjek penelitian ini memiliki kesetiaan yang tinggi terhadap pekerjaannya. Tingginya komitmen afektif membuktikan bahwa para karyawan bekerja di PT. " $\mathrm{X}$ " tersebut tidak menganggap pekerjaannya hanya sebagai rutinitas semata, melainkan para karyawan merasa memiliki ikatan emosional perusahaan tersebut. Para karyawan juga bangga menceritakan hal - hal positif tentang perusahaan dimana mereka bekerja kepada orang lain. Ikatan sosial emosional yang baik membuat employee perceived service quality yang dimiliki oleh karyawan juga baik sehingga karyawan (dalam hal ini pramuniaga) memiliki orientasi pada pelanggan dalam memberikan pelayanan dengan cukup baik juga.

Hasil analisis regresi penelitian ini memberikan sumbangan efektif variabel orientasi pada pelayanan pelanggan (Customer Service Orientation) yang ditunjukkan melalui koefisien determinasi $\left(\mathrm{R}^{2}\right)$ sebesar 0.266. Angka tersebut menunjukkan bahwa komitmen afektif memiliki sumbangan terhadap variabel orientasi pada pelayanan pelanggan (Customer Service Orientation) sebesar 26.6 $\%$, sisanya sebesar $73.4 \%$ harus dijelaskan oleh faktor-faktor lain yang tidak disertakan dalam penelitian ini. Kecilnya sumbangan efektif variabel komitmen afektif pada variabel orientasi pada pelayanan pelanggan (Customer Service Orientation) Pramuniaga PT. "X" di Semarang diperkirakan karena adanya harapan dan kebutuhan pramuniaga akan keterikatan emosional individu secara organisasional belum terpenuhi secara optimal. Meskipun pramuniaga memiliki semangat dalam bekerja dan memiliki inisiatif untuk melakukan usaha secara maksimal dalam melayani pelanggan namun ada kebutuhan lain yang menjadi harapan pramuniaga yaitu jenjang karir di perusahaan tersebut.

Pada umumnya pramuniaga memiliki kompetensi orientasi layanan pelanggan (Customer Service Orientation) yaitu memiliki kemampuan untuk melaksanakan atau melakukan suatu pekerjaan atau tugas 
yang dilandasi atas ketrampilan dan pengetahuan serta didukung oleh sikap kerja yang dituntut oleh pekerjaan tersebut. Hal tersebut dapat diperkuat dengan memasukkan kompetensi dalam uraian tugas agar mendorong karyawan untuk bekerja lebih efektif (Tas, dkk, dalam Vathanopas \& Thai-ngam, 2007).

\section{SIMPULAN}

Hasil analisis regresi sederhana menunjukkan bahwa terdapat hubungan positif dan signifikan antara komitmen afektif dengan orientasi pelayanan pelanggan (Customer Service Orientation) dengan koefisien korelasi $\left(\mathrm{r}_{\mathrm{xy}}\right)=0,516$ dengan $\mathrm{p}<0,001$. Dari hasil tersebut peneliti merekomendasikan saran kepada perusahaan untuk memberikan pelatihan kompetensi CSO dengan tujuan untuk meningkatkan pramuniaga dalam berkinerja lebih dari biasa agar mereka mampu berkinerja superior.

\section{DAFTAR PUSTAKA}

AlHarbi, A., Heavin, C., \& Carton, F. (2016) Improving customer oriented decision making through the customer interaction approach. Journal of Decision Systems, 25(1), 50-63, doi: 10.1080/12460125. 2016.1187417

Becker, B.E., Huselid, M.A., \& Ulrich, D. (2001). The HR scorecard: Linking people, strategy, and performance. Boston: Harvard Business Press

Dessler, G. (2005). Manajemen sumber daya manusia. Jilid 2. Jakarta : Gramedia

Finka, L. (2014). The effect of customer focus competence on construction project performance. Procedia Social and Behavioral Sciences, 119 ,427-436

Greenberg, L. \& Baron, R. A. (2003). Behavior in organizations: Understanding and managing the human side of work. Upper Saddle River. New Jersey : Pearson Education, Inc.

Kartika, E. W. (2011). Analisis pengaruh leader-member exchange, perceived organizational support, dan komitmen organisasional ter-hadap organizational citizenship behavior pada karyawan hotel berbintang lima di Surabaya. Tesis tidak dipublikasikan. Surabaya: Universitas Airlangga.

Luthans, F. (2005). Organizational behaviour. New York : McGraw Hill.

Meyer, J. P., Allen, N. J., \& Smith, C. A. (1993). Commitment to organizations and occupations : Extension and test or a three - component conseptualization. Journal of Applied Psychology, 78(4), 538-551

Meyer, J. P., Stanley, D. J., Herscovitch, I., \& Topolnytsky. (2002). Affective, continuance and normative commitment to the organization : a meta analysis of antecedents, correlates, and consequences. Journal of Vocational Behavior. 61(1), 20-52

Neuman, W. \& Lawrence. (2007). Social research methods: Qualitative and quantitative approaches. Boston : Allyn and Bacon

Nurandini, A. (2014). Analisis Pengaruh Komitmen Organisasi Terhadap Kinerja Karyawan (Studi pada Pegawai Perum Perumnas Jakarta). Skripsi. Fakultas Ekonomika Dan Bisnis. Semarang: Universitas Diponegoro

Rhoades, L., Eisenberger, R. \& Armeli, S. (2001). Affective commitment to the organization: the contribution of perceived organizational support. Journal of Applied Psychology, 86(5): 825-836. 
Sabir, M. S., Sohail, A., \& Khan, M. A. (2011). Impact of leadership style on organization commitment : In A Mediating Role of Employee Values. Journal of Economics and Behavioral Studies. 3(2), 145-152.

Schultz, D., \& Schultz, S. E. (2002). Psychology and work today. Eight Edition. New Jersy : Prentice Hall Inc.

Siswanto, J. (2006). Pengembangan alat ukur kompetensi individu. Modul pelatihan. Bandung : ASB

Spencer, L. M., \& Spencer, S. (1993). Competence at work models for superior performance. Canada : John Wiley \& Sons, Inc.

Tjiptono, F. (2007), Strategi Pemasaran. Edisi ke dua. Yogyakarta : Andi
Vathanophas, V., \& Thai-ngam, J. (2007). Competency requirements for effective job performance in the Thai public sector. Contemporary Management Research, 3(1), 45-70

Wulandari, W. (2008). Hubungan antara persepsi terhadap pengembangan karir dengan komitmen afektif pada pegawai Bank Jateng kantor pusat. Skripsi. Semarang: Fakultas Psikologi UNDIP

Yuliane, R. (2003). Rasa percaya, komitmen organisasi dan rasa berdaya tim (empowered team) pada karyawan instansi pemerintah di Surabaya. Anima. 18( 3), 23-30.

Zwell, M.(2000). Creating culture of competence. New York: John Wiley $\&$ Sons.Inc 